\title{
SABER MUSICAL SENSÍVEL NAS ESCOLAS DE EDUCAÇÃO BÁSICA BRASILEIRAS: PERSPECTIVAS, DIMENSÕES E FUNDAMENTOS
}

Thaís Lobosque Aquino*

\begin{abstract}
Resumo: $\mathrm{O}$ artigo se propõe a refletir sobre as perspectivas, dimensões e fundamentos do saber musical sensível em escolas de educação básica brasileiras. Parte constituinte de uma pesquisa teórica voltada a pensar a epistemologia da educação musical escolar (AQUINO, 2016), tem-se como pressuposto o fato de o saber musical escolar ser um tipo de saber sensível e, como tal, capaz de fomentar modos de operar articuladores de aspectos comumente percebidos como incompatíveis e, por conseguinte, apreendidos e vivenciados de forma dissociadora na contemporaneidade. À medida que são estabelecidas as relações imanentes entre seus fundamentos éticos, cognitivos, emocionais e somáticos, suas dimensões científicas, filosóficas e artísticas, bem como as relações extrínsecas com outros campos do saber, acredita-se contribuir para a construção de alicerces epistemológicos mais claros para a educação musical nas escolas brasileiras de educação básica.
\end{abstract}

Palavras-chave: saber musical sensível; educação musical escolar; educação básica.

Resumen: En este artículo se pretende reflexionar sobre las perspectivas, dimensiones y fundamentos del saber musical sensible en las escuelas de educación básica en Brasil. Parte constitutiva de una investigación teórica que se centró em el pensamiento de la epistemología de la educación musical escolar (AQUINO, 2016), se supone que el saber musical escolar es un tipo de saber sensible y, como tal, capaz de fomentar modos de operación articuladores de aspectos comúnmente percibidos como incompatibles y, por lo tanto, capturados y experimentados de manera disociadora hoy en día. A medida que se establecen las relaciones inmanentes entre sus fundamentos éticos, cognitivas, emocionales y físicas, sus dimensiones científicas, filosóficas y artísticas, así como las relaciones extrínsecas con otros campos del conocimiento, se cree hacer una contribución a la construcción de claros fundamentos epistemológicos para la educación musical en las escuelas brasileñas de educación básica.

Palabras claves: saber musical sensible; educación musical escolar; educación básica.

\section{Prólogo}

Parte de uma pesquisa de doutorado voltada ao estudo teórico da epistemologia da educação musical escolar (AQUINO, 2016), este trabalho intenta pensar o saber musical tendo em vista as relações imanentes de seus fundamentos e suas dimensões, bem como as relações

* Doutora em Educação pela Faculdade de Educação da Universidade Federal do Rio de Janeiro (FE/UFRJ) e professora adjunta na Escola de Música e Artes Cênicas da Universidade Federal de Goiás (EMAC/UFG). Endereço eletrônico: tlobosque@hotmail.com. extrínsecas que estabelece com outros campos do saber, com outros saberes escolares. Acredita-se que ambas as relações, se conectadas e colocadas em permanente prisma crítico, podem participar na construção de alicerces epistemológicos mais claros para a educação musical nas escolas básicas brasileiras.

Antes de qualquer ponderação, é essencial esclarecer que o termo "saber" não é empregado de modo arbitrário e é preferido a expressões como "conhecimento", "disciplina" e "ciência" sem, todavia, descartá-los. Isso porque

AQUINO, Thaís Lobosque. Saber musical sensível nas escolas de educação básica brasileiras: perspectivas, dimensões e fundamentos. Revista Sul-Americana de Filosofia e Educação. Número 29: nov./2017-abr./ 2018, p. 116-136. DOI: https://doi.org/10.26512/resafe.v0i29.21010 
"saber" sugere sentidos mais amplos, envolvendo "[...] todo um conjunto de conhecimentos metodicamente adquiridos, mais-ou-menos sistematicamente organizados e susceptíveis de serem transmitidos por um processo pedagógico de ensino." (JAPIASSU, 1975, p. 15).

Assim, o conceito de "saber" pode referir-se tanto a conhecimentos de ordem prática quanto aos propriamente intelectuais e teóricos, tanto àqueles com maior apelo racional quanto aos que privilegiam dimensões sensíveis, tanto a campos com bom nível de sistematização quanto aos que estão em vias de se constituírem $e$, ainda, àqueles mais difusos e espontâneos. Saber engloba toda uma gama de conhecimentos de caráter técnico, reflexivo, científico, filosófico, artístico e/ou corporal, passíveis de serem internalizados em processos de ensino e aprendizagem.

$\mathrm{O}$ saber musical tem forte potencial para constituir-se como "saber sensível" (ENTEL, 2008) capaz de impulsionar modos de operar articuladores de aspectos comumente percebidos como incompatíveis $e$, por conseguinte, apreendidos $e$ vivenciados de forma dissociadora. O termo "saber sensível" busca integrar, em sua própria estrutura gráfica, o sensível e o inteligível, além de outras tantas dicotomias que vêm cristalizando visões fragmentárias nos processos de pensar e fazer humanos ${ }^{1}$.

1 O conceito de "saber sensível" ora construído difere-se daquele cunhado por Duarte Júnior (2000) cuja influência tem se mostrado significativa no campo da educação estética. Nas palavras do autor: "[...] situando-se a meio caminho entre a vida vivida e a abstração conceitual, as formas artísticas visam a significar esse nosso contato carnal com a realidade, e a sua apreensão opera-se bem mais através de nossa sensibilidade do que via o intelecto." (ibid, p. 25). Como se percebe, seu posicionamento termina por antepor os aspectos sensíveis/corporais da arte àqueles mentais/intelectuais, gerando uma hierarquização, ideia refutada pelos argumentos deste trabalho.
Afirmar que a atividade musical pode colocar em movimento diversos âmbitos humanos, não significa a formação de um esquema lógico simplista, do qual resulta que o trabalho pedagógico com os saberes musicais conduza, necessariamente, à mobilização igualitária de razão e emoção, teoria e prática, técnica e reflexão, mente e corpo. No entanto, parece importante explicar que, ao lidar com os saberes musicais, podemos tanto construir conceitos e modos de operar próprios da linguagem musical quanto (re)elaborar emoções estéticas suscitadas pelas atividades musicais; tanto teorizar sobre conteúdos sonoros quanto colocá-los concomitante e/ou imediatamente em prática ou ouvindo, ou cantando, ou tocando; tanto voltar a atenção para preocupações eminentemente técnicas quanto para reflexões sobre possíveis implicações de cada técnica em particular, e da linguagem musical como um todo, sobre os processos humanos de conhecer; tanto usar a mente musical quanto o corpo sonoro para novos modos de pensar e estar no mundo.

\section{Pelo rompimento com os modos de conhecer legitimados}

Na obra Dialética de lo Sensible: Imágenes entre Leonardo y Walter Benjamin, Entel (2008) dedica-se a realizar uma cartografia dos modos de elaborar os conhecimentos na contemporaneidade. Segundo a intelectual argentina, o contexto atual se caracteriza pela vigência de políticas neoliberais que vêm reforçando a injustiça social, bem como a adaptação ao que está posto, tolhendo os indivíduos de imaginarem outras experiências políticas, econômicas, culturais, cognitivas e artísticas em longo prazo. Fazendo frente à experiência do desencanto $e$ à falta de horizontes utópicos, propõe o 
reencantamento do mundo, mediante atitudes que rompam com os modos de conhecer legitimados pelo status quo e que, ao fim e ao cabo, promovam a justiça social.

Durante sua investigação, a autora constata a hegemonia dos saberes inteligíveis, despojados da sensibilidade em sentido amplo, desde o advento da Modernidade e que perdura até os dias atuais. Para Entel (2008), as dicotomias razão/sensibilidade, trabalho/contemplação, corpo/alma, para citar algumas, são efeitos de uma lenta e profunda construção consciente da alienação pelo sistema educativo $e$ associa-se com o ideal iluminista de conhecer através da substituição por generalização, em que o pensamento abstrato é considerado o desiderato do pensamento humano.

A consequência inevitável é a estigmatização do sensível e dos modos de conhecer relacionados de alguma forma com a sensibilidade, como é o caso dos saberes artísticos, não raro acusados de superficialidade, posto que associados à ideia romântica da arte como inspiração $e$ não como é verdadeiramente: um trabalho processual e sistemático.

Isso ajuda a entender algumas razões para a secundarização ou o silenciamento do trabalho pedagógico com o saber musical, entendido como saber sensível, nas escolas de educação básica brasileiras. Apesar de aparecer em atividades recreativas, em momentos lúdicos, como auxiliar na internalização de diferentes conhecimentos, e até mesmo quando presente como disciplina curricular, a música na escola parece oscilar entre dois extremos: de um lado, a tentativa de valorizar seu aspecto cognitivo através de práticas que, no afã de recobrirem-na de uma áurea de seriedade, acabam incorrendo em ações pedagógicas tradicionais e, por outro, aquelas que, ao privilegiarem seu caráter sensível, matizamse pelo mote da livre-expressão, caindo na armadilha do espontaneísmo.

Esse abismo não possui apenas componente pedagógico: é também político, histórico, epistemológico. Concatena-se com o processo descrito por Entel (2008) da legitimação gradual da supremacia dos conhecimentos inteligíveis, da construção ideológica do pensamento abstrato como pretensão máxima das experiências escolares, do rebaixamento da sensibilidade e das emoções nos processos de conhecer, e da consequente alienação que tais divisões acarretam, na medida em que obstruem a criação de formas integradoras de perceber e transformar o mundo.

Diante desse panorama e imbuída pelo projeto marcusiano, Entel (2008) lança luzes sobre a emergência de uma relação não alienada entre razão e emoção, mediada pela imaginação, cuja possibilidade de concretude sobrevém pela arte. Segundo a autora, a instauração de uma ordem política mais justa só acontecerá, realmente, quando vier acompanhada por uma mudança cultural que propicie uma nova poética e novos modos de conhecer capazes de emancipar os imaginários e as representações.

Para a autora, caberia à arte, na qualidade de força social propiciadora de uma nova sensibilidade, a conjunção entre razão e emoção. Se as lógicas políticas, epistemológicas e escolares vêm historicamente estigmatizando o sensível $e$ os saberes por ele abarcados, incluídos aí os saberes musicais, o que se propõe não é uma virada de cento e oitenta graus em que a sensibilidade passaria a tiranizar as esferas inteligíveis. A ideia é redimensionar o sensivel em conjunção com o inteligível para a construção de horizontes mais justos. 


\section{Sobre as perspectivas do saber musical sensivel}

O saber musical está inserido num campo dinâmico de relações onde se tensionam fundamentos, dimensões $e$ perspectivas. Os fundamentos dizem respeito aos seus eixos medulares. As dimensões, aos seus aspectos artísticos, filosóficos e científicos, uma vez que a música é uma linguagem da arte e pode ser elaborada filosófica e/ou cientificamente, embora não seja stricto sensu nem ciência, nem filosofia. As perspectivas compreendem as articulações que o saber musical estabelece com outras vias compreensivas.

Com efeito, as discussões sobre os saberes musicais escolares não se localizam exclusivamente no campo da educação musical, porém cumpre salientar que compete a esse campo integrar os aportes dos demais. Pensando por imagens, seria como um campo magnético onde os saberes musicais se ligassem por linhas imaginárias, em diferentes direções e com distintas magnitudes, a diversos campos do saber mais ou menos sistematizados, formando um campo vetorial com forte concentração em torno da educação musical.

O trabalho de Kraemer (2000) é representativo no detalhamento da natureza do "conhecimento pedagógico-musical" pela via das inter-relações que estabelece com outras "disciplinas". O autor alemão cataloga os aspectos filosóficos, históricos, psicológicos, sociológicos, políticos, musicológicos e pedagógicos do conhecimento pedagógico-musical e pontua as características de cada uma das disciplinas relacionadas a cada um desses aspectos.

Ao fazê-lo, defende que a pedagogia da música trata sempre do objeto estético "música", dividindo-o com as chamadas "ciências humanas"; está, pois, entrelaçada com outras disciplinas. Em seguida, explica que o conhecimento pedagógico-musical diz respeito a mais pessoas do que geralmente se supõe e surge em muitos lugares. Por conseguinte, não se dá exclusivamente nos institutos científicos, sequer concerne apenas a professores de música: é um conhecimento difundido por vários agentes em diversos contextos sociais.

Ressalte-se que as ideias de Kraemer (2000) têm sido tomadas como parâmetros de referência para se pensar o conhecimento pedagógico-musical, a pedagogia da música, bem como os fundamentos da educação musical no Brasil (DEL-BEN, 2003a, 2003b; KLEBER, 2006; LOUREIRO, 2003; e SOUZA, 2007, 2014).

De fato, sua sistematização é importante, especialmente se observado o momento de sua publicação no Brasil, no início dos anos 2000, quando inúmeras categorias fundantes do campo seguiam invisibilizadas. Perceber o oportuno avanço do autor faz acender a vontade de estabelecer um diálogo vivo, elaborado pelo confronto dinâmico de argumentos, que pode fazer emergir outras possibilidades epistemológicas para a educação musical brasileira.

Um primeiro ponto a ser problematizado refere-se à opção do autor por pensar a natureza do conhecimento pedagógico-musical tão somente pela via de suas relações com outros campos disciplinares. Não há como negar as contribuições desses campos, mas não deixa de incomodar uma análise que escamoteia a discussão dos aspectos imanentes dos saberes musicais. Além da relação que travam com outras perspectivas compreensivas, cumpre indagar: quais são seus fundamentos? E mais: de que forma esses fundamentos se articulam com outros 
campos do saber para formar o corpus epistemológico da educação musical?

Outra questão diz respeito à predileção do autor pelas terminologias "pedagogia musical" e "conhecimento pedagógico-musical". No prefácio de seu artigo, redigido por Jusamara Souza, há a informação de que, na literatura alemã, "pedagogia musical" designa a área como ciência e "educação musical" se refere às práticas educativo-musicais. É estabelecida, pois, uma diferenciação entre a teoria científica, incorporada pela palavra pedagogia, e as ações educativo-musicais, enunciadas como educação musical. Essa separação e a consequente preferência do autor por uma análise epistemológica da pedagogia musical podem conduzir à cisão entre teoria e prática, colocando a primeira em posição privilegiada.

Há que se considerar o fato do termo "pedagogia" responder a certa necessidade em elevar o campo a um status científico. Entretanto, a dimensão científica é um dos ângulos sob os quais a educação musical pode ser apreendida, não o único, nem o mais importante: tanto a dimensão filosófica quanto a artística são igualmente caras ao campo.

Em função disso, prefere-se, aqui, a denominação "educação musical" a "pedagogia da música", porque, além de estar mais arraigada no campo ${ }^{2}$, possui caráter mais amplo, podendo se referir às dimensões científicas, filosóficas e artísticas do fenômeno educativo-musical, bem como aos seus enfoques teóricos e práticos, racionais e sensíveis, mentais e corporais, técnicos e reflexivos. A própria grafia do termo "educação musical" concorre para revelar seu sentido: um campo formado

\footnotetext{
${ }^{2}$ A título de exemplo, a própria associação de classe que congrega os profissionais no Brasil tem o nome de Associação Brasileira de Educação Musical (ABEM) e seus membros são habitualmente chamados de "educadores musicais".
}

pela interseção fundamental entre a educação e a música, que se abre ao encontro com outras perspectivas do saber humano, que inclui, mas não privilegia, a dimensão científica.

Seguindo um raciocínio similar, a expressão "conhecimento pedagógicomusical", largamente utilizada por Kraemer (2000), é, nesta investigação, substituída por "saberes musicais", termo com maior potencial para abarcar manifestações musicais mais ou menos sistematizadas, mais ou menos espontâneas, passíveis de serem trabalhadas em processos pedagógicos de ensino mais ou menos formalizados por diferentes sujeitos em diversas situações de ensino-aprendizagem.

\section{Sobre as dimensões do saber musical sensível}

A educação musical toma parte de um campo de tensões, juntamente com outras perspectivas compreensivas, ocupando uma posição diferenciada, uma vez que articula as contribuições de todos os outros campos do saber para lançar luzes sobre os fundamentos do saber musical escolar, tendo em vista suas dimensões artísticas, filosóficas $e$ científicas.

\section{Sobre a dimensão científica}

A penetração das ideias de Kraemer (2000), o aumento de cursos de pósgraduação em música, o incremento de congressos, o fortalecimento de publicações $e$ as diretrizes dos órgãos de financiamento educacional têm contribuído para o crescimento das análises científicas em educação musical. Souza (2007) analisa a área como ciência, ou seja, como um sistema produtor de um corpo de conhecimentos e de resultados de pesquisas sob três aspectos: 1) quem são os investigadores, 2) quais os meios de produção do conhecimento e 3) como a 
área se encontra e funciona em relação a outras estruturas e instituições.

De acordo com a autora, os pesquisadores, em sua grande maioria, advêm de programas de pós-graduação em música ou em áreas afins - como educação, história e psicologia - e seus interesses $e$ posicionamentos estão ligados às linhas de pesquisa de seus respectivos programas.

Com relação aos meios de produção do conhecimento, a autora afiança que os princípios epistemológicos que fundamentam as teorias $e$ as práticas em educação musical haviam sido discutidos nos últimos encontros da Associação Brasileira de Educação Musical (ABEM), onde se percebeu a proeminência de publicações de relatos de pesquisa sobre o estado da arte da educação musical no Brasil, a formação de educadores musicais, além de temas emergentes como educação musical não formal e espaços alternativos, processos de autoaprendizagem, $e$ educação musical e mídias. Para Souza (2007), o surgimento de temas antes proscritos, a consequente criação de novos GT's nos encontros da ABEM $e$ a introdução no Brasil da sistematização proposta por Kraemer (2000) teriam sido responsáveis por uma "virada epistemológica" na área.

Sobre o terceiro e último aspecto, a autora segue lisonjeira ao afirmar que a educação musical possui um grau de independência considerável em relação a outras subáreas do campo da música, reconhecidas pelas agências governamentais como a Comissão de Aperfeiçoamento de Pessoal do Nível Superior (CAPES) e o Conselho Nacional de Desenvolvimento Científico e Tecnológico (CNPq). Além disso, aponta que tem havido intervenções significativas $e$ concretas, especialmente realizadas pela ABEM, associação modelo para os demais países da América Latina, cuja liberdade e possibilidade de autodeterminação têm propiciado definir seus próprios caminhos.

O artigo de Souza (2007) corrobora o entendimento da educação musical como ciência e é representativo de concepções voltadas à elaboração da área por intermédio do pensamento $e$ dos procedimentos científicos. Acontece que suas ideias parecem obnubiladas por um otimismo acentuado.

Por exemplo, atestar o aumento das discussões sobre os princípios epistemológicos da área nos encontros da ABEM não significa, necessariamente, um avanço considerável da área no tocante à reflexão (auto)crítica de seus fundamentos. Para isso, são necessários numerosos esforços em várias direções, especialmente em trabalhos teóricos que se debrucem a pensá-los com sistematicidade e rigor.

Do mesmo modo, a emergência de novos temas e a incorporação das ideias de Kraemer (2000) não conduzem, diretamente, a uma virada epistemológica. Em verdade, o que há é uma virada temática, que pode vir a se transformar numa virada epistemológica, caso se faça acompanhar por uma mudança consciente e radical no conteúdo, na organização, na formação, no desenvolvimento e nas formas de objetivação das produções do campo.

Focalizar apenas as conquistas da ABEM e tomá-la como modelo para a América Latina pode conduzir a compreensões idealizadas da associação que possui diversos entraves internos $e$ externos a serem problematizados, apesar de, indubitavelmente, ter sua importância atestada pelos mais de vinte anos de construção coletiva para a consolidação do ensino de música no Brasil.

Outro ponto que merece ser debatido diz respeito ao fato de que, mesmo a autora estabelecendo um recorte definido sobre sua intenção em abordar a dimensão científica da educação musical, em sua 
análise não há menção ao filosófico $e$ ao artístico, podendo significar um modo de conceber fragmentário. Seria como se para a educação musical ser reverenciada como ciência, ao lado das demais áreas do conhecimento já consolidadas, fosse preciso unidimensionalizar seu aspecto cognitivo/racional/científico, alijando-a de seus potenciais filosóficos, estéticos e sensíveis.

Analisar a educação musical unicamente pela via do pensamento científico ou então dimensionar o saber musical como um tipo de saber científico, isto é, fruto de um sistema de generalizações conceituais arbitrárias $e$ sistemáticas, conduz a um encolhimento de seus potenciais imanentes, que incluem o espontâneo e o intuitivo. $\mathrm{O}$ saber musical escolar se relaciona com o saber científico tanto por aproximações, travando vínculos de correlação e dependência, quanto por distanciamentos, estabelecendo desvios que acabam por associá-lo a um "saber sensível" e, como tal, com vias de desenvolvimento $e$ modos de funcionamento diferentes, em que pesem as possibilidades de articulação com dimensões filosóficas e artísticas.

\section{Sobre a dimensão filosófica}

Lazzarin (2005a, 2005b, 2006) discute as contribuições da Filosofia da Educação Musical (FEM), proposta Bennett Reimer, e da Nova Filosofia da Educação Musical (NFEM), de David Elliott, que nascem de uma necessidade de justificativa da educação musical como disciplina nas escolas norte-americanas. Segundo o autor, tanto a FEM quanto a NFEM aspiram a um pensamento crítico e sistemático sobre a área da educação musical e tentam explicar a natureza dos processos de conhecimento envolvidos na experiência com a música, possuindo, pois, preocupações epistemológicas. Todavia, a última incorpora as contribuições do multiculturalismo e da ciência cognitiva, posicionando-se criticamente em oposição à primeira.

A despeito disso, o autor elucida que as duas têm mais em comum do que se pode pensar. Ambas tentam justificar a presença da educação musical nas escolas sob as mesmas bases instrumentais das outras disciplinas curriculares, isto é, por meio do modelo científico tradicional. Inusitadamente, ambas sobrevalorizam a dimensão científica da educação musical, com tentativas mais voltadas à dominar a complexidade da experiência com música que à sua compreensão. Logo, o sentido da palavra "filosofia" acaba reduzido ao conjunto de conhecimentos responsáveis por sustentar as ações educativas e o estabelecimento da natureza da experiência musical se torna tão somente o ponto de partida para a fixação de propostas educativo-musicais na escola.

Com posicionamento diferente dos autores analisados por Lazzarin, Adorno (1995) aproxima-se de alguns fundamentos da filosofia e do pensamento filosófico, quando pondera sobre a prova geral de filosofia dos concursos para a docência em ciências nas escolas superiores do estado de Hessen na Alemanha.

O intelectual alemão esclarece que essa prova visava avaliar se os candidatos conseguiam ir além de seus conhecimentos profissionais estritos, se eram capazes de realizar reflexões acerca do que fazem e de si mesmos, enfim, se eram "pessoas de espírito". O próprio autor alerta para o fato de essa expressão remeter a uma espécie de arrogância, até certo ponto repugnante, e ironiza: "[...] a expressão 'pessoa de espírito' pode ser repugnante, mas só nos damos conta de que existe alguém assim a partir de algo ainda mais repugnante, ou seja, o fato de alguém ser uma pessoa sem espírito." (ibid., p. 55). 
Enquanto esmiúça o processo das referidas provas, Adorno (1995) revela a atitude dos candidatos em procurar por caminhos seguros em normas $e$ conhecimentos já consolidados, o que demonstra a reificação ou coisificação de suas consciências, em muito inaptas ao exercício do pensamento livre e autônomo. Os futuros professores de ciências das escolas superiores do estado de Hessen procuravam se orientar conforme as regras científicas, acercando-se de ciência e de seus rituais linguísticos e procedimentais, como antídotos para a reflexão intelectual do factual. Portanto, no lugar do discernimento, instalava-se a frase ideológica, ao invés da elaboração filosófica viva, havia alienação. Isso porque,

[...] a filosofia é percebida como um peso morto que dificulta a aquisição de conhecimentos úteis, seja na preparação das disciplinas principais, prejudicando o progresso nessa área, seja na aquisição de conhecimentos profissionais. A filosofia submetida a exame converteu-se em seu contrário; em vez de conduzir os que se ocupam dela ao encontro de si mesmos, prestase apenas a demonstrar a todos o fracasso da formação cultural, não só no caso dos candidatos, mas de um modo geral. (ibid., p. 69).

Segundo Adorno (1995), a formação cultural depende da disposição intrépida $e$ da capacidade de se abrir a elementos do espírito, apropriando-os tanto com consciência como com amor, palavra que o autor assumiria se não fosse pelo temor de ser interpretado equivocadamente como sentimental: "[...] eu diria que para haver formação cultural se requer amor; $e$ o defeito certamente se refere à capacidade de amar." (ibid, p. 64).

Além da carência na formação cultural, relacionada às debilidades nas formas de conhecer que articulem razão $e$ emoção, havia o encolhimento dos potenciais da filosofia que, de acordo com o autor, não pode reduzir-se a um apêndice das disciplinas científicas. A filosofia possui autonomia, contudo se comunica com as ciências particulares como possibilidade de resistência, por meio do pensamento crítico sobre o real, a que se opõe a apropriação alienada e coisificada dos conhecimentos: é (auto)conscientização viva do espírito.

Das ponderações adornianas, depreende-se que, se exercido com fundamentação e comprometimento deliberado, o pensamento filosófico pode gerar reflexões prenhes de discernimento das contradições encerradas nos processos emancipatórios de (auto)conscientização $e$ (auto)crítica. Nesse sentido, pode em muito contribuir na construção de alicerces epistemológicos para a educação musical $e$ na estruturação dos saberes musicais escolares.

Entretanto, cumpre ressaltar: porquanto o saber musical não seja um tipo de saber científico, igualmente não se constitui em um tipo de saber filosófico, embora possa ser pensado tanto científica quanto filosoficamente.

A propósito, os modos de operar científicos e filosóficos são diferentes, porém podem se articular, evitando rompimentos que culminem em absolutizações ou equivalências que levem a indiferenciações. Quer dizer, Filosofia(s) e Ciência(s) podem se relacionar dialeticamente por fluxos que coloquem em prismas críticos suas idiossincrasias e suas correlações.

Não obstante, há um ponto de convergência insigne: ambas lidam com os movimentos, as dinâmicas $e$ os desenvolvimentos dos conceitos, ainda que a primeira trabalhe precipuamente com os científicos e a segunda com os filosóficos. Esmiuçando um pouco mais: ambas tendem a sustentar que a transição da percepção à representação sistemática 
acontece mediante processos de abstração $e$ generalização responsáveis pela formação de sistemas conceituais, forma principal da atividade do pensamento humano $e$ finalidade eminente do ensino escolar.

Os processos de formação dos conceitos científicos e dos conceitos filosóficos pelos alunos ocorrem, sobretudo, por meio de conhecimentos teóricos expressos verbalmente pelo uso da linguagem oral ou da linguagem escrita cuja unidade semântica é a palavra. Uma vez que tendem a privilegiar o racional $e$ o verbal, seguem minimizando, ou até suprimindo, formas não-verbais de conhecer vinculadas à sensibilidade.

Sem perder de vista essas dissociações, que ainda dominam os modos de operar científicos e filosóficos na contemporaneidade, parece razoável supor que ambos possam fomentar "saberes sensíveis", desde que comprometidos em desenvolver com intencionalidade trabalhos agregadores. Em face disso, mesmo que aspectos históricos, políticos e epistemológicos tenham conduzido a dicotomizações, posturas críticas podem nortear ciência(s) e filosofia(s) a realizações integradoras.

\section{Sobre a dimensão artística}

Singularmente, o modo de operar artístico pressupõe o uso de formas nãoverbais ligadas ao visual, às imagens, ao sonoro, à música, ao gestual, à dança, ao cênico, sem excluir a linguagem verbal. Outrossim, lida com conceitos, embora não seja propriamente conceitual, efetua abstrações e generalizações, embora não as entronizem como propósitos soberanos.

Ora, há como depreender elementos essenciais do modo de operar artístico pelo jogo entre disparidades e conformidades, mais ou menos complexas, com os modos de operar científico e filosófico. Pensando em uma discrepância rudimentar: a(s) ciência(s) tende $(\mathrm{m})$ a privilegiar a formação de conceitos científicos e a(s) filosofia(s) a de conceitos filosóficos ${ }^{3}$, ambas pela via racional, enquanto $\mathrm{a}(\mathrm{s})$ arte $(\mathrm{s})$ tende $(\mathrm{m})$ à interligação dos saberes pelo exercício da não dissociação.

Ressalte-se que por mais que o modo de operar artístico seja potencialmente integrador, não é necessariamente integrador. Isso quer dizer que seus fundamentos imanentes o predispõem, no entanto não o determinam a tal. Para que a potência se transforme em ato, é necessária a mediação de um trabalho pedagógico que reconheça os saberes artísticos como "saberes sensiveis".

Se os saberes artísticos tendem a integrar, os "saberes sensíveis" tensionam conscientemente à integração. Por isso, o saber musical escolar, fruto de trabalho pedagógico intencional, sistemático e com pretensões emancipatórias agregadoras, estabelece-se precipuamente como "saber sensível" articulador de aspectos percebidos $e$ vivenciados de forma dissociada, para a construção de modos de operar que façam frente às fragmentações epistemológicas, sociais e econômicas dominantes.

Considerando que este trabalho opta por um modo de operar entrecortado pela (auto)crítica, pela formação de sistemas categoriais e pelo exercício integrador de razão e emoção pode, a todo momento, ser (auto)reflexionado em prismas críticos ou ser reorganizado em termos conceituais, ou ser reposicionado sob novas bases sensíveis. Por ora, parece pertinente retomar que o campo de tensões dos saberes musicais

\footnotetext{
3 Segundo Türcke (2004): "Pensar não é senão transformar realidade em conceitos. Mas é justamente este processo de transformação que tende a iludir o pensamento a respeito de seu próprio alcance, sugerindo-lhe uma capacidade de se encaixar sem resíduo a realidade em suas gavetas conceituais, ou seja, sugerindo-lhe a congruência de seus conceitos e da realidade por eles captada." (ibid., p. 54).
} 
escolares, entendidos como "saberes sensíveis", é complexo e se constrói por articulações de diferentes propriedades seja com outras perspectivas compreensivas humanas, seja com suas dimensões científica, filosófica e artística, seja com seus fundamentos imanentes. Se até aqui foram avivadas perspectivas e dimensões, remanesce trazer à baila os fundamentos dos saberes musicais sensíveis.

\section{Sobre os fundamentos do saber musical sensível}

Se para Entel (2008), a mediação da dicotomia entre inteligível e sensível se realiza pela arte, para Adorno (2008), essa mediação acontece pela via da moral ${ }^{4}$. Sem concordar ou discordar completamente dos dois intelectuais da Teoria Crítica e tratando mais especificamente do ensino de música em escolas de educação básica, a proposta é de uma reorganização em que essa unidade seja promovida por saberes musicais sensíveis, ancorados em fundamentos éticos, cognitivos, emocionais e corporais, e impulsionados por trabalhos pedagógicos integradores em educação musical.

\section{Sobre o fundamento ético}

Evidentemente, não há educação musical escolar desvencilhada de valores éticos. A ética ${ }^{5}$ constitui-se em sustentáculo

\footnotetext{
${ }^{4}$ Para o autor, "[...] seria tarefa da filosofia procurar na oposição entre sentimento $e$ intelecto a sua unidade: exatamente aquela dada pela moral." (ADORNo, Op. Cit., p. 194).

${ }^{5}$ Concordamos com Oliveira (2012) acerca das distinções entre o que pertence ao domínio da ética e ao domínio da moral: "[...] consideramos mais significativo não distinguir tais domínios, salientando que a reflexão, o julgamento $e$ as decisões não são vistos como momentos particulares do sujeito ético, nem as ações consideradas boas ou virtuosas como prerrogativas do sujeito moral, sendo ambos compreendidos como indissociáveis. Tomamos, então, ética e moral como instâncias intercambiáveis
}

do processo pedagógico escolar nos mais diversos níveis, contextos e práticas da educação básica. Mais do que isso, é pilar substancial da existência humana. A todo tempo, refletimos, julgamos e tomamos decisões que orientam nossas ações em contextos multifacetados. Por conseguinte, a ética permeia e subsidia a vida social, a educação escolar e a educação musical escolar, configurando-se como possibilidade de elaboração crítica de costumes, tradições e valores, em âmbito individual e coletivo.

Neste trabalho, parte-se da premissa de que os fundamentos éticos dos saberes musicais sensíveis trabalhados nas escolas de educação básica têm como eixos as categorias antinômicas de humanização, emancipação e justiça social.

O processo de humanização, isto é, o exercício de tornar-se gente, está carregado de ambiguidades, afinal não ocorre em uma trajetória retilínea, harmônica e segura. Ao contrário, e evitando qualquer resquício idealista, acontece por movimentos contraditórios ora progressivos, ora retrógrados, ora diretos, ora tortuosos. Em razão disso, parece crucial o reconhecimento da realidade histórica $e$ dolorosa do seu oposto, a desumanização ou, como prefere Adorno, a barbárie.

\begin{abstract}
Qualquer debate acerca de metas educacionais carece de significado $e$ importância frente a essa meta: que Auschwitz não se repita. Ela foi a barbárie contra a qual se dirige toda a educação. Fala-se da ameaça de uma regressão à barbárie. Mas não se trata de uma ameaça, pois Auschwitz foi a regressão; a barbárie continuará existindo enquanto persistirem no que tem de fundamental as condições que
\end{abstract}

que se referem aos mesmos objetos: valores, hierarquias de valores, princípios e hábitos que orientam as reflexões $e$ as ações do homem no contexto de suas múltiplas relações." (ibid., p. 124). 
geram esta regressão. É isto que apavora. (ADORNO, 1995, p. 119).

Constatar a desumanização em contextos reais, concretos e objetivos seja em Auschwitz, seja no cotidiano das salas de aulas brasileiras, suscita a urgência por ações pedagógicas que incrementem o seu reverso: a humanização. Humanizar-se ou humanizar-nos pressupõem esforços incansáveis que resistam crítica $e$ sensivelmente às constantes tentativas de anulação do sujeito e de arrefecimento do compromisso coletivo para com a construção de uma sociedade mais justa.

Contudo, tais esforços estão embebidos de contradições. A nosso ver, todo e qualquer conteúdo ético da educação musical escolar dirige-se para a reflexão factual, crítica e sensível da negatividade da dinâmica emancipatória. Reiterar a negatividade da emancipação significa despojá-la de seus ecos redentores.

Seguindo essa linha de raciocínio, para deixar de ser coisa, objeto destituído de sentimento, o homem precisa empenharse na direção de uma reflexividade sensível que o impulsione ao antinômico exercício da humanidade. Os caminhos para tal intento são vacilantes, repletos de dúvidas $e$ entrecortados por situações mais ou menos brandas de dominação e de barbárie que solapam a conquista coletiva por justiça social.

Então, não se trata de reconciliar-se com "bons valores" previamente estabelecidos, mas em trafegar eticamente com a consciência sensível das contradições da dinâmica emancipatória, sem perder de vista a luta por uma distribuição cada vez mais igualitária dos bens sociais, incluindo os saberes musicais: é a humanização que, em face da existência objetiva da desumanização, não se petrifica, embora se assombre, esforçando-se com afinco para fazer-se viva.
Além de se movimentarem pelos sinuosos caminhos da emancipação, da humanização e da luta por justiça social, os propósitos éticos da educação musical escolar aparecem como potenciais articuladores entre razão e emoção. Se o objetivo primeiro da formação musical é formar gente, combatendo situações que extirpem os sujeitos de suas condições humanas, não há como fazê-lo por fragmentações.

Dessa feita, a integração sensível/inteligível caminha lado a lado com o projeto ético mais amplo da educação musical escolar e é materializada pelo trabalho pedagógico cotidiano com os saberes musicais sensíveis. $\mathrm{O}$ que se quer trazer a lume é a ética humanizadora em sua dialética com o todo e as partes: é tanto aspecto macro, norteador de reflexões $e$ ações em educação musical nas escolas de educação básica, quanto fundamento estruturante dos saberes musicais sensíveis.

Cada conteúdo programático desses saberes - sejam relacionados à teoria musical, à história da música, à apreciação, à improvisação, à composição, ao arranjo ou à performance - possui fundamento ético. Donde se depreende que, em cada conteúdo musical trabalhado nas turmas da educação básica, está contida (ou não) a possibilidade de humanização. Portanto, é no território das ambiguidades da emancipação, da articulação entre razão $e$ sentimento e da luta por justiça social, presentes nos conteúdos específicos dos saberes musicais sensíveis, que sementeia uma educação musical de qualidade nas escolas brasileiras.

\section{Sobre o fundamento cognitivo}

Ademais, essa qualidade pode ser buscada a partir de outros fundamentos dos saberes musicais sensíveis, entre eles, o intelectivo/ cognitivo/ mental/ racional. Uma breve análise da trajetória da educação 
musical brasileira faz notar o dualismo histórico entre abordagens que privilegiam o trabalho com os elementos intelectivos da música, ou melhor, com conceitos musicais, por vezes em matizes tradicionais, e aquelas que, no afã de rebatê-las, radicalizam os lemas da livre expressão, da criatividade, da liberdade, da improvisação, do desenvolvimento sensível, escamoteando os conteúdos nos processos musicais escolares. É como se houvesse um embate e ora triunfasse a cognição, ora a sensibilidade.

Com efeito, essa disputa é inócua porque a experiência musical - desdobrada nas atividades de compor, improvisar, arranjar, tocar, cantar, apreciar, refletir possui caráter multidimensional, sendo, ao mesmo tempo, cognitiva, emocional, ética e corporal.

Diante disso, pode-se sustentar que o propósito do ensino de música em escolas de educação básica se relaciona ao trabalho com os saberes musicais sensíveis para impulsionar o desenvolvimento moral, mental, sensível e corporal dos alunos, de maneira que sejam capazes de ponderar, sentir e agir musicalmente, em níveis paulatinamente mais elaborados de conhecimento e sensibilidade.

Nos vários ensaios da obra Introdução à Sociologia da Música, Adorno (2011) analisa a função cognoscitiva da experiência musical, por meio de um exercício de pensamento que busca capturar provisoriamente o negativo, que estaria fora da unidade dada pelos conceitos já existentes, num movimento incessante que se abre para o contraditório. $\mathrm{O}$ autor toma como premissa o fato de as obras musicais serem estruturas sonoras materialmente experimentáveis, passíveis de serem comunicadas, interpretadas $e$ compreendidas, e cujos conteúdos de verdade aparecem quando revelam, nos meandros internos de suas formas, os antagonismos não resolvidos na realidade social. Quanto mais uma obra, por sua própria dinâmica intrínseca, coloca-se ante a experiência do antagonismo, mais comprometida está com aquilo que é verdadeiro, ou seja, com uma experiência musical capaz de fazer frente à falta de compreensão e à completa indiferença com relação ao material sonoro.

Para Adorno (2011), a música não é reflexo da sociedade, tampouco a sociedade é reflexo da música: o vínculo entre ambas não pode ser pensado em moldes unidirecionais. Música e sociedade se aproximam, interpenetrando-se, e se distanciam, diferenciando-se, em movimentos ininterruptos que formam um campo de tensão intrincado, onde as obras musicais passam a se apropriar das antinomias sociais tornando-as suas próprias.

Consoante esse entendimento, podese afirmar que as obras musicais são antíteses sociais da sociedade, embora não devam ser deduzidas imediatamente dela 6 . Em outras palavras, o social é inerente às suas estruturas formais $e$ aos seus mais ínfimos elementos internos. Cada nota, cada figura rítmica, cada acento métrico, cada variação de intensidade constitui-se em materialização histórica de forças coletivas que agem em contradição, posto que "[...] a realização do específico pressupõe sempre qualidades que são adquiridas para lá dos limites da especificação." (ADORNO, 1970, p. 58).

A consciência de que a música possua material próprio e opere conforme suas próprias leis formais, sem perder a tensão com o social, conduz ao entendimento de que uma experiência musical qualificada seja aquela que promova a apreensão dos fenômenos sonoros em suas complexas implicações e que possibilite aos sujeitos a

\footnotetext{
${ }^{6}$ Em analogia à afirmação: "A arte é a antítese social da sociedade, e não deve imediatamente deduzir-se desta." (ADORNO, 1970, p. 19).
} 
formação de representações internas, simbólicas e estruturais das relações significativas do material musical. Assim sendo, a experiência musical é fundamentalmente, e não prioritariamente, uma experiência cognitiva.

Adorno (2011) defende de modo rigoroso que a experiência musical precisa se pautar no desenvolvimento da capacidade de exploração musical, no conhecimento de conteúdos consistentes $e$ relevantes para além da análise isolada do detalhe, na consciência do musicalmente essencial, no estabelecimento de interrelações bem fundamentadas a partir do domínio da lógica musical imanente às obras e na reflexão conceitual prenhe de discernimento. A experiência musical é, pois, ativa, viva e depende de uma formação que habilite cognoscitivamente o indivíduo a desenvolver relações qualificadas e imaginativas com os elementos musicais.

A partir das ponderações adornianas, e já dialogando com expoentes da Teoria do Ensino Desenvolvimental, parece plausível considerar que aprender música nas escolas de educação básica teria relação com a apropriação da(s) cultura(s) musical(is) e com o desenvolvimento do modo de operar propriamente musical, que inclui generalizações conceituais relativas tanto aos conteúdos dos saberes musicais sensíveis em si quanto às ações mentais correspondentes a forma de constituição desses conteúdos. Quer dizer, os alunos se apropriam não somente dos conceitos musicais, mas dos procedimentos lógicos, investigativos e imaginativos com os quais

7 A Teoria do Ensino Desenvolvimental vêm demonstrando as implicações práticas da Teoria Histórico-Cultura,l inicialmente concebida por Lev S. Vigotski (1896-1934). Para este artigo foram consultados: Davydov (1986, s.d); Freitas (2011); Libâneo (2004, 2009, 2011); Libâneo e Freitas (2007, 2013). os músicos trabalharam ao formularem seus produtos musicais.

Pensando com os referidos expoentes - cujo entendimento pressupõe que o bom ensino seja aquele que impulsione o desenvolvimento mental dos alunos, por meio de processos ativos de internalização capazes de transformar as formas culturais, externas, coletivas, extrapsíquicas em abstrações conceituais intrapsíquicas conclui-se que o bom ensino de música estaria relacionado à promoção do desenvolvimento mental dos alunos, por intermédio de atividades mobilizadoras de generalizações sistemáticas e conscientes, dirigidas à formação de conceitos musicais.

Ainda que concordemos com várias premissas dos representantes da Teoria do Ensino Desenvolvimental, questionamos, primeiramente, a hegemonia ocupada pelo desenvolvimento mental como escopo dos processos musicais escolares, fato que pode desdobrar-se em propostas pedagógicomusicais mentalistas que fragmentam $e$ hierarquizam os fundamentos dos saberes musicais sensíveis. Em segundo lugar, questionamos a soberania dos conceitos abstratos, teóricos e científicos que minora as possibilidades de interiorização de saberes menos sistematizados, ou de saberes de ordem prática, ou daqueles que integram concretude e abstração, como é o caso dos saberes musicais sensíveis.

$\mathrm{O}$ processo de ensino e aprendizagem da música em escolas de educação básica tem potencial para promover $\mathrm{O}$ desenvolvimento intelectivo dos alunos, bem como seus desenvolvimentos emocionais, éticos e somáticos. Além disso, tal processo pode promover a construção de conceitos teórico-científicos pela via da abstração por generalização e, também, contribuir para a elaboração de conceitos de cunho filosófico e artístico, mais ou menos sistematizados, cujas trajetórias de 
internalização nem sempre acontecem pelo paradigma da abstração reflexiva.

De fato, aprender música é aprender a pensar, ponderar, sentir e agir musicalmente mediante atividades, conceitos $e$ procedimentos musicais. Mesmo com variações de conteúdos e aprofundamento ao longo dos diversos níveis da educação básica, tal aprendizagem não pode distanciar-se de experiências de escuta, performance e reflexão musical que, valendo-se dos conceitos e dos modos de operar próprios da música, viabilizem a construção de "[...] referenciais de percepção internalizados que permitam identificar, no fato sonoro, os atributos que caracterizam os elementos musicais." (PENNA, 2012, p. 59).

Portanto, o desenvolvimento dos alunos depende da apropriação de conceitos dos saberes musicais sensíveis constituídos historicamente pela humanidade em contextos e situações diversas. A eles não podem deixar de serem oferecidos os meios de domínio dos modos próprios de pensar e de atuar da música para a formação de capacidades intelectuais, emocionais e de atuação prática com base na reflexão crítica dos procedimentos lógicos, investigativos e sensiveis do campo musical. Na presença desses argumentos, a educação musical escolar teria sua qualidade comprometida pela desconsideração dos conceitos e dos modos de operar musicais, ou melhor, se deixar de lado a preocupação com o fundamento cognitivo imanente do saber musical sensível.

\section{Sobre o fundamento emocional}

Além dos fundamentos éticos $e$ cognitivos, o saber musical sensível abarca os sentimentos, a imaginação, a fantasia e o corpo. Aos juízos morais, aos conceitos e aos modos de operar musicais, somam-se os elementos emocionais e somáticos; sem eles tais saberes perderiam sua força expressiva.

Quando abordam o vínculo entre música e emoção, Pederiva e Tunes (2013) demonstram que o estudo das emoções tem sido historicamente negligenciado, em virtude do entendimento corrente de que os sentimentos interfeririam desfavoravelmente nas investigações racionais. É como se as emoções fossem um resquício abominável da condição animal que teima em permanecer nos indivíduos, dificultandolhes o pleno exercício do intelecto. Segundo as autoras, isso tem feito com que a vida intelectual $e$ a vida afetiva sejam estudadas separadamente, embora um peso maior seja dado ao estudo da primeira, "[...] causando um entendimento parcial da própria questão intelectual. É como tentar entender a água, que somente pode ser compreendida pela configuração global de sua molécula, considerando apenas o hidrogênio ou o oxigênio, isoladamente." (ibid, p. 105).

A dissociação entre pensamento $e$ sentimento também é denunciada no aforismo Sacrifício do Intelecto, integrante da Minima Moralia de Adorno. Para o autor, a mera suposição de que o pensamento poderia se beneficiar em termos objetivos com o declínio das emoções indica $\mathrm{O}$ processo de embrutecimento dos indivíduos. De igual modo, relegar a imaginação à competência do inconsciente ou excluíla do conhecimento, como rudimento pueril desprovido de conteúdo, conduz à castração da percepção, à morte do desejo $e$ ao sacrifício do intelecto. Pensamento $e$ sentimento desenvolvem-se na interação $e$ acabam encolhidos quando apartados um do outro: "[...] tão logo esteja apagado o último traço de emoção, só resta ao pensamento a tautologia absoluta." (ADORNo, 2008, p. 119). 
Com base na análise de pesquisas em psicologia, Vigotski (2010) constata que a teoria das emoções ou dos sentimentos é pouco estudada, embora haja pontos de vista justos sobre a natureza das reações emocionais. $\mathrm{O}$ autor explica ser esse aspecto do comportamento humano o mais difícil de descrever, classificar e relacionar, devido ao seu caráter essencialmente subjetivo.

Vigotski (2010) entende que a emoção não é um agente menor que o pensamento e analisa sua dupla natureza biológica e psicológica -, demonstrando suas ligações com os instintos e com as reações psíquicas ativas que organizam internamente o comportamento. Daí deriva a necessidade de uma educação dos sentimentos que é sempre uma reeducação dirigida à mudança no sentido da reação emocional inata. Sobre isso acrescenta algo interessante: que o aspecto emocional deve ser objeto de preocupação da educação nas mesmas proporções em que o são a inteligência e a vontade.

Para Vigotski (1999), existe um tipo de emoção específica, aquela suscitada pela experiência estética, responsável por uma descarga de sentimentos a serem resolvidos em movimentos expressivos. De acordo com o intelectual russo, a arte trabalha um pensamento emocional peculiar, diferente da emoção comum, cujos efeitos são mais complexos e sutis, já que vincula o afeto ao intelecto e não se traduz em ações imediatas e diretas:

Deste modo, o traço distintivo da emoção estética é precisamente a retenção de sua manifestação externa, enquanto conserva ao mesmo tempo uma força excepcional. Poderíamos demonstrar que a arte é uma emoção central, é uma emoção que se resolve predominantemente no córtex cerebral. As emoções da arte são emoções inteligentes. Em vez de se manifesta- rem de punhos cerrados e tremendo, resolvem-se principalmente em imagens da fantasia. (VIGOTSKI, 1999, p. 267).

O sentimento artístico possui certa natureza orgânica geral por suscitar reações reflexas, motoras, somáticas e secretórias. Todavia, sua manifestação física tende a ser sublimada pela atividade da imaginação, expressão central da reação emocional estética. Enquanto as emoções comuns tendem a se resolver em ações físicas imediatas, as emoções estéticas conservam suas forças no exercício da fantasia: são emoções cognitivas, pensantes, inventivas, permanentemente reelaboradas pelas experiências sociais $e$ individuais dos sujeitos.

Outro ponto evidenciado por Vigotski (1999) diz respeito às emoções estéticas encerrarem inúmeras contradições, suscitando uma série de sentimentos híbridos, com sentidos opostos, que entram em curto-circuito, destruindo-se e reelaborando-se. O princípio da antítese, ao ser elaborado pela atividade da fantasia, transforma emoções inicialmente elementares em reações emocionais expressivas pensantes, em suma, em emoções estéticas. A esse efeito da obra de arte, o autor denomina "catarse":

[...] nenhum outro termo dentre os empregados até agora na psicologia, traduz com tanta plenitude e clareza o fato central para a reação estética, de que as emoções angustiantes $e$ desagradáveis são submetidas a certa descarga, à sua destruição $e$ transformação em contrários, e de que a reação estética como tal se reduz, no fundo, a essa catarse, ou seja, à complexa transformação dos sentimentos. (VIGOTSKI, 1999, p. 270).

As ponderações vigotskianas sobre a relação entre arte e sentimento são pontos 
de partida para os entendimentos ora esboçados sobre o fundamento emocional dos saberes musicais sensíveis.

Primeiramente, há um vínculo entre a emoção musical e os fundamentos cognitivos do saber musical sensível, visto que tal emoção tende a reelaborar cognitivamente as reações emocionais rudimentares, bem como os sentimentos contraditórios suscitados pelas obras musicais, por meio do exercício inteligente da fantasia. Isso não significa que as emoções musicais estejam apartadas das reações somáticas, quer dizer que tais reações são reelaboradas pela atividade criadora da imaginação cujo desenvolvimento depende das experiências individuais e sociais dos sujeitos.

Nesse sentido, as emoções deflagradas pelos saberes musicais sensíveis se abrem à intelecção e à imaginação, ambas imbricadas nos processos de formação musical escolar cujos sentidos se constroem pelo desenvolvimento de saberes sensíveis $e$ de modos de operar sensíveis atentos às antinomias presentes nos conteúdos e nas formas musicais. O fundamento emocional dos saberes musicais sensíveis tem a ver, justamente, com o enfrentamento consciente dos sentimentos antinômicos suscitados pelas obras musicais, através do movimento catártico que transforma qualitativamente as emoções musicais pela experiência, individual e social, da imaginação.

\section{Sobre o fundamento somático}

Por fim, e não menos considerável, há que se demonstrar o fundamento somático dos saberes musicais sensíveis, em interconexão com o ético, o cognitivo e o emocional. A relação entre o corpo e a experiência musical parece evidente, afinal, é a partir do aparato corpóreo que a música é produzida, vivenciada e compreendida. A música é feita pelo corpo e para o corpo e não é apenas pelo aparelho receptor, composto pelo sistema de órgãos especiais dos sentidos, que lidamos com ela. $\mathrm{O}$ estímulo musical percorre o aparelho central desencadeando processos psicofísicos que acontecem no interior do organismo. Esses, não raro, são convertidos pelo aparelho respondente em reações motoras mais ou menos voluntárias, mais ou menos conscientes. Logo, a experiência musical desencadeia uma série de complexas reações internas e externas que tendem a mobilizar aspectos psíquicos e físicos.

Desenvolver processos pedagógicomusicais em escolas de educação básica que desconsiderem a corporeidade seria o equivalente a extirpar da experiência musical sua concretude. Só sabemos com o corpo inteiro, isto é, com intelecto, com valores, com sentimentos e com o exercício inteligente do corpo. Mesmo com essa convicção, soaria ingênuo ignorar a marginalização histórica dos sentimentos $e$ da corporeidade nas mais diversas esferas humanas quer na vida cotidiana, quer em elaboradas produções teóricas, quer na educação escolar, quer nas aulas de música. Afetos e gestos nos ligam de alguma forma aos instintos, ao prazer e à materialidade, aspectos continuamente reprimidos pela marcha civilizatória humana.

No esboço Interesse pelo corpo, que se encontra ao final da Dialética do Esclarecimento, Adorno e Horkheimer (1985) afirmam que, por trás da história conhecida da Europa, corre, subterrânea, a história dos instintos e das paixões humanas recalcados e desfigurados pela civilização. Para os autores, essa espécie de mutilação que compartimenta e hierarquiza trabalho $e$ desfrute tem afetado, sobretudo, a relação com o corpo. Sua identificação com o mau, em contrapartida à ideia do espírito como sumo bem, fez com que os indivíduos estigmatizassem os corpos, o seu e o de outrem, em relações marcadas pela 
irracionalidade e pela injustiça da dominação, ambas afastadas de compreensões reflexivas nutridas pela liberdade e pela felicidade.

Contudo, a corporeidade humana não é vivenciada apenas pela via da crueldade. O corpo escarnecido e repelido como algo inferior é, simultaneamente, desejado como o proibido. $\mathrm{Na}$ civilização ocidental $e$, segundo os autores, provavelmente em toda civilização, o corpo é tabu, objeto de atração e repulsão, gerando relações de amor e ódio, que acabam por reificá-lo, alienando-o de si mesmo: "[...] não se pode mais reconverter o corpo físico [Körper] no corpo vivo $[$ Leib]. Ele permanece um cadáver, por mais excitado que seja." (ADORNO E HORKHEIMER, 1985, p. 192) [grifos dos autores].

Os autores alemães fazem a crítica a uma construção histórica da noção de corpo pelos extremos emocionais do amor $e$ do ódio, pelos moralismos que o unidimensionalizam como fonte perniciosa de desejos lascivos, pelas dualidades esfaceladas que $\mathrm{O}$ circunscrevem à irracionalidade. A relação patogênica $e$ irrefletida com o corpo faz-se acompanhar pela mutilação das consciências e pela deterioração das subjetividades, em muito incapazes de dialetizar os substratos materiais e psíquicos da existência, em muito capazes de converter o corpo em algo morto.

$\mathrm{Na}$ qualidade de repositório do lado mais atroz, mais animal, mais bárbaro dos homens, contra o corpo deveriam se voltar vigorosamente os processos civilizatórios humanos, dentre os quais, a educação escolar. À medida que a corporeidade é extirpada de seus potenciais humanizadores, bem como desvinculada de pensamentos sensíveis e emoções elaboradas, torna-se obstáculo aos processos educacionais como um todo e à educação musical escolar de modo específico.

Essa ideia ajuda a entender o número incipiente de propostas pedagógicas sistemáticas que ponderem o corpo em sua dialética com os aspectos intelectivos, éticos $e$ emocionais nas escolas de educação básica brasileiras. Reduzir a corporeidade a dimensões primitivas e indômitas, destituindo-lhe de consciência $e$ sensibilidade, é o mecanismo central de situações sociais concretas que a degredam da escolarização.

Saliente-se que conhecer as circunstâncias históricas que vêm reprimindo o exercício inteligente, ético $e$ sensível da corporeidade nas instituições escolares é condição para compreensões articuladoras do fundamento somático dos saberes musicais sensiveis. Segundo Storolli (2011), no campo específico da educação musical, a atenção dispensada ao corpo tem se resumido a um treinamento específico com o objetivo de desenvolver habilidades como, por exemplo, o domínio performático de um instrumento. Para a autora, o corpo não se constitui apenas como ferramenta a ser treinada para a obtenção de certos resultados, sendo o principal agente e, muitas vezes, o próprio local da prática musical. Por isso, a importância em compreender seu funcionamento e entender mais acerca de sua natureza e seus processos.

Storolli (2011) aponta que as investigações sobre o corpo ganham maior relevância, sobretudo, a partir de meados do século XIX, passando por mudanças significativas ao longo de todo o século XX. Nas décadas de 1980 e 1990, a autora nota o despontar de pesquisas que tendem a relacionar diversos campos do conhecimento, ultrapassando fronteiras disciplinares, e que vêm abrindo caminhos diferenciados para o estudo da corporeidade. Muitos desses estudos têm se 
voltado a perceber o corpo através de sua atuação no mundo, por meio das manifestações em que ele seja um fator fundamental - caso das atividades performáticas musicais -, de modo a propor alternativas para as dicotomias até então predominantes entre corpo e mente, razão $e$ emoção.

A autora parte para a defesa da necessidade de se estimular práticas que privilegiem a ação do corpo e viabilizem processos criativos integradores dos aspectos somáticos e inteligíveis da música. Seriam trabalhos com o movimento $e$ a investigação de sua natureza pela via da experimentação e da improvisação, para o aprimoramento da percepção corporal nas mais diversas atividades relacionadas à experiência musical. Storolli (2011) demonstra com clareza ser inaceitável minorar a consciência do corpo nas situações da prática e do ensino de música, posto que os conhecimentos somáticos, as ações gestuais e os movimentos corporais são inseparáveis de uma aprendizagem musical viva.

Embora a autora seja arrojada ao demonstrar a importância da corporeidade nos processos cognitivos e ao propor a inclusão do trabalho corporal consciente nas aulas de música, seria interessante pensarmos o corpo no interior de um campo de tensões mais complexo, onde tomam parte não só a cognição, mas também as emoções e a ética. Isso porque os corpos pensam, ponderam, reagem emocionalmente, organizam emoções elaboradas e tornam evidentes em seus mais ínfimos gestos os valores morais da sociedade e do indivíduo. Enfim, em seus movimentos sucessivos, coparticipam sejam como substratos, ou como agentes na catarse das emoções estéticas, na construção de conceitos sensíveis e na incessante luta por humanização.
Mesmo consciente da marginalização histórica da corporeidade nos estudos científicos e em outras instâncias da cultura, mesmo sabendo que as investigações mais sistemáticas a seu respeito sejam recentes, não há como desconsiderar ou diminuir a importância dos fundamentos somáticos na educação escolar, em termos amplos, e na educação musical escolar, em termos específicos. O corpo é substancial em processos pedagógicos em que o objetivo seja a internalização ativa e a externalização sonora dos saberes musicais sensíveis, juntamente com as ponderações éticas, os conceitos e os modos de operar musicais, $e$ as emoções estéticas.

Em vista disso, não é unicamente pela ação mental que se realiza o desenvolvimento musical dos alunos nas escolas de educação básica brasileiras. Aos processos de abstração por generalização, que se valem das operações cerebrais para a apreensão sistemática e sistêmica dos conceitos musicais, integram-se o exercício vivo das capacidades sensório-motoras, bem como a elaboração imaginativa das emoções musicais e das ações éticas.

\section{Epílogo}

Os saberes musicais sensíveis mobilizam e transformam os binômios abstração/sensibilidade, corpo/mente, cognição/emoção, trabalho/contemplação, valores/sentimentos, colocando-os em movimentos de tensão permanente entre si, viabilizando aos alunos pensar emocionalmente, sentir inteligentemente, discernir valores sensivelmente e exercitar consciente $e$ imaginativamente seus corpos sonoros.

Portanto, a articulação - não apenas dos fundamentos, mas entre eles, as dimensões $e$ as perspectivas dos saberes musicais sensíveis - é a bússola orientadora 
de uma educação musical escolar de qualidade. Não basta mobilizar conceitos musicais ou emoções estéticas, ou uma ética humanizadora, ou uma corporeidade consciente; não bastam enfoques ou científicos, ou artísticos, ou filosóficos; não basta a mera vinculação da educação musical com outros campos do saber. Acredita-se que com empenho constante em imaginar, pensar, incorporar e praticar todos esses aspectos, tensionando para não dissociar e contradizendo para desvelar, a educação musical escolar tenha maior possibilidade de impulsionar um trabalho qualificado com os saberes musicais sensíveis nas escolas básicas brasileiras.

\section{Referências}

ADORNO, T. W. Teoria estética. $2^{\mathrm{a}}$ ed. Lisboa: Edições 70, título original de 1970.

Educação e emancipação. $7^{\mathrm{a}}$ impressão. Rio de Janeiro: Paz e Terra, 1995.

Minima Moralia: reflexões a partir da vida lesada. Rio de Janeiro: Beco do Azougue Editora, 2008.

Adorno, T. W.; HoRKheIMER, M. Dialética do esclarecimento: fragmentos filosóficos. Rio de Janeiro: Jorge Zahar Ed, 1985.

AQUINO, Thaís Lobosque. Epistemologia da educação musical escolar. um estudo sobre os saberes musicais nas escolas de educação básica brasileiras. 2016. 225 p. Tese (Doutorado em Educação) - FE/UFRJ, Rio de Janeiro/RJ, 2016.

DAVYDOV, V. V. "Problemas do ensino desenvolvimental - a experiência da pesquisa teórica e experimental na psicologia". 1986. Textos publicados na Revista Soviet Education, august, vol. XXX, $\mathrm{n}^{\circ}$ 8, sob o título Problems of Developmental Teaching. The Experience of Theoretical and Experimental Psycholgogical Research - Excerpts, de V.V.
Davídov, a partir do original russo. Traduzido por José C. Libâneo e Raquel A. M. da M. Freitas. Trabalho não publicado.

"O problema da generalização e do conceito na teoria de Vygotskij". Studi di Psicologia dell'Educazione. Vol. 1, 2, 3. Armando, Roma. Trabalho não publicado. S.d.

DEL-BEN, Luciana. "Múltiplos espaços, multidimensionalidade, conjunto de saberes: idéias para pensarmos a formação de professores de música". Revista da ABEM. Porto Alegre, v. 11, n. 8, p. 29-32. mar. 2003a.

"A pesquisa em educação musical no Brasil: breve trajetória e desafios futuros". Per Musi. Belo Horizonte, v. 7, p. 76-82, 2003b.

DUARTE JÚNIOR, João F. $O$ sentido dos sentidos. a educação (do) sensível. 2000. 234 p. Tese (Doutorado em Educação) FE/UNICAMP, Campinas/SP, 2000.

Entel, Alicia. Dialética de lo Sensible: Imágenes entre Leonardo y Walter Benjamin. Buenos Aires: Aidos editores, 2008.

FREITAS, Raquel A. M. da M. "Aprendizagem e formação de conceitos na teoria de Vasili Davydov". In: LIBÂNEO, J. C.; SUANNO, Marilza V.; LimONTA, Sandra V. (Orgs.). Concepções e práticas de ensino num mundo em mudanças: diferentes olhares para a didática. Goiânia: Editora da PUC/CEPED Publicações, 2011.

JAPIASSU, Hilton. Introdução ao pensamento epistemológico. Rio de Janeiro: Livraria Francisco Alves Editora S. A, 1975.

KLEBER, Magali. "Educação musical: novas ou outras abordagens - novos ou outros protagonistas". Revista da ABEM. Porto Alegre, v. 14, n. 14, p. 91-98, mar. 2006.

KRAEMER, Rudolf-Dieter. "Dimensões $e$ funções do conhecimento pedagógico- 
musical". Trad. Jusamara Souza. Em Pauta: Revista do Programa de Pós-Graduação em Música da Universidade Federal do Rio Grande do Sul, v. 11, n. 16/17, p. 51-73, abr./nov. 2000.

LAZZARIN, Luís F. "A natureza da experiência com música nas 'filosofias' da educação musical". Anais da 28 Reunião Anual da ANPEd. Caxambu, p. 1-14, 2005a.

"Por uma critica à Nova Filosofia da Educação Musical". Revista Educação $e$ Realidade. Porto Alegre, v. 30, n. 1, jan./jul., p. 103-124, 2005 b.

"A dimensão multicultural da nova filosofia da educação musical". Revista da $A B E M$. Porto Alegre, v. 14 , n. 14 , p. $125-$ 131, mar. 2006.

LIBÂNEO, José C. "A didática $e$ a aprendizagem do pensar e do aprender: a teoria histórico-cultural da atividade e a contribuição de V. Davydov". Revista Brasileira de Educação. Rio de Janeiro, n. 27, p. 5-24, dez. 2004.

"Teoria histórico-cultural e metodologia de ensino: para aprender a pensar geograficamente". Texto apresentado no XII Encuentro de Geógrafos de América Latina, abril/2009, Universidad de la República, Montevideo, Uruguay. 2009.

"Didática e trabalho docente: a mediação didática do professor nas aulas". In: LiBÂNEO, J. C.; SUANNO, Marilza V.; LimONTA, Sandra V. (Orgs.). Concepções e práticas de ensino num mundo em mudança. Goiânia: CEPED/PUC-Goiás, 2011.

LiBÂNEO, J. C; FreITAS, Raquel A. M. da M. "Vygotsky, Leontiev, Davídov contribuições da teoria histórico-cultural para a didática". In: SILVA, C. C.; SUANNO,
M. V. R. (Orgs.). Didática e interfaces. Rio de Janeiro/ Goiânia: Descubra, 2007.

"Vasily Vasilyevich Davydov - a escola e a formação do pensamento teóricocientífico". In: LONGAREZI, Andréa M.; PUENTES, Roberto V. (Orgs.). Ensino Desenvolvimental: vida, pensamento e obra dos principais representantes russos. Uberlândia: Editora Edufu, p. 47-65, 2013.

Loureiro, Alicia M. A. O ensino de Música na escola fundamental. Campinas: Papirus, 2003.

Oliveira, Renato J. de. "Contribuições da racionalidade argumentativa para a abordagem da ética na escola". Educação e Pesquisa. São Paulo, v. 38, n. 1, p. 115130, 2012.

PeDERIVA, Patrícia Lima Martins; TUNES, Elizabeth. Da atividade musical e sua expressão psicológica. Curitiba: Prismas, 2013.

PenNA, Maura. Música(s) e seu ensino. $2^{\text {a }}$ ed. rev. e ampl. Porto Alegre: Sulina, 2012.

SouZA, Jusamara V. "Pensar a educação musical como ciência: a participação da ABEM na construção da área". Revista da $A B E M$. Porto Alegre, v. 15 , n. 16, p. 25-30, mar. 2007.

"Sobre as várias histórias da educação musical no Brasil". Revista da ABEM. Londrina, v. 22, n. 33, p. 109-120, jul./dez. 2014.

StOROLl, Wânia M. A. "O corpo em ação: a experiência incorporada na prática musical". Revista da ABEM. Londrina, v. 19, n. 25, p. 131-140, jan.jun. 2011.

TÜRCKE, Cristoph. "Pronto-socorro para Adorno: fragmentos de uma dialética negativa". In: ZuIN, Antônio A. S.; PucCI, Bruno; RAMOS-DE-OliveIRA, Newton (Org.). Ensaios frankfurtianos. São Paulo: Cortez, 2004. 
VIGOTSKI, L. S. Psicologia da arte. $3^{\mathrm{a}}$ ed.

São Paulo: Editora Martins Fontes, 1999.

Psicologia pedagógica. $3^{\mathrm{a}}$ ed. São

Paulo: Editora WMF Martins Fontes, 2010.

Recebido em: 09/03/2018

Aprovado em: 10/04/2018 